\title{
MOLECULAR CHARACTERIZATION OF THREE hiS4 DELETION MUTANTS IN SACCHAROMYCES CEREVISIAE
}

\author{
by \\ STEEN HOLMBERG, MORTEN C. KIELLAND-BRANDT, \\ TORSTEN NILSSON-TILLGREN ${ }^{1}$ and JENS G. LITSKE PETERSEN \\ Department of Physiology, Carlsberg Laboratory \\ Gamle Carlsberg Vej 10, DK-2500 Copenhagen Valby \\ and \\ 'Institute of Genetics, University of Copenhagen \\ Oster Farimagsgade 2A, DK-1353 Copenhagen K
}

Keywords: Yeast, HIS4 gene, deletions, molecular hybridization

\begin{abstract}
DNA was isolated from haploid strains of Saccharomyces cerevisiae carrying three different deletions in the his 4 gene, his4-15, his4-24 and his4-29, as well as a his4 point mutant and a strain carrying the HIS4 wild type gene. Samples of the DNA preparations were treated with restriction endonucleases BamHI, EcoRI, HindIII, PstI and SalI and the DNA fragments were separated according to size by agarose gel electrophoresis. A bacterial plasmid containing the yeast DNA sequences of a region including the HIS4 gene allowed the detection by molecular hybridization of the fragments in the electropherograms that contained these sequences. From the sizes of these fragments the mutations his $4-15$ and his $4-24$ were both determined to be deletions of about $0.5 \mathrm{~kb}$, while his 4-29 was found to be a deletion of approximately $0.9 \mathrm{~kb}$. The data allowed an extension of our previously constructed cleavage map of the region as well as an approximate location of the deletions on the map. Comparisons with available data on the his 4 gene and its product allowed an approximate positioning of the three functional regions of the his 4 gene on the map and indicated that no large intervening sequences are present within the his $4 A B$ region.
\end{abstract}

\section{INTRODUCTION}

The HIS4 gene in yeast encodes the enzymatic activities catalyzing the $3 \mathrm{rd}(H I S 4 A)$, 2nd $(H I S 4 B)$ and the 10th $(H I S 4 C)$ steps in the pathway of histidine biosynthesis (2). A great number of point mutants and several deletion mutants have been isolated and used for genetic mapping of the region $(3,4)$. Genetic (7) and biochemical studies (1) employing various nonsense, missense and frameshift mutations have shown that the HIS4 gene codes for a single polypeptide (molecular weight 95,000) which contains three domains coded for by $H I S 4 A$, $H I S 4 B$ and $H I S 4 C$ respectively. Each domain 
has one of the three enzymatic activities and the direction of translation of the HIS4 messenger RNA is from $H I S 4 A$ to $H I S 4 C$.

In the accompanying paper (5) we have reported the construction of several plasmids which contain a $9.4 \mathrm{~kb}$ yeast chromosomal DNA sequence including the HIS4 gene. In one of these plasmids, pC502, the $9.4 \mathrm{~kb}$ segment is carried on the bacterial plasmid pBR325. Using molecular hybridization with radioactive $\mathrm{pC} 502$ DNA, we have in the present study determined the sizes of different restriction endonuclease fragments originating from the HIS4 region. By comparison of the data for three different his 4 deletion mutants with the wild type pattern the approximate physical positions and sizes of the deletions were determined.

\section{MATERIALS AND METHODS}

The following haploid Saccharomyces cerevisiae strains were used as sources of DNA: S288C (HIS4), IV-1 (his4-260), K5-5A (his415), C75-M23 (his4-24) and C75-M26 (his429). Strain $\mathrm{S} 288 \mathrm{C}$ is a prototrophic reference strain from which the his4 mutations were derived $(3,4)$. The complete genotypes of the other strains have been given (6).

The preparation of total yeast DNA has been described (6). The DNA was further purified by adding $1.24 \mathrm{~g} \mathrm{CsCl}$ per ml of DNA solution followed by centrifugation at $40,000 \mathrm{rpm}$ in a Beckman $50 \mathrm{Ti}$ rotor at $15^{\circ} \mathrm{C}$ for 48 hours. Fractions containing DNA were selected according to viscosity, pooled, precipitated with ethanol and dissolved in $10 \mathrm{~mm}$-Tris- $\mathrm{HCl}, 0.1 \mathrm{~mm}$ EDTA, pH 7.5.

Autoradiographic exposure was for 2 to 7 days with or without Kodak X-Omatic regular intensifying screens. All other methods used in this study have been described (5).

\section{RESULTS}

DNA was isolated from yeast strains carrying the deletions his4-15, his4-24 and his4-29. For comparison, DNA was also prepared from a strain carrying the his $4-260$ point mutation and a histidine prototrophic strain (HIS4). Samples of each of the 5 DNA preparations were digested with the restriction endonucleases PstI, EcoRI,
BamHI, SalI and HindIII and subjected to electrophoresis in $0.7 \%$ agarose. After electrophoresis the DNA in the gel slab was transferred to a sheet of cellulose nitrate filter as described by SoUTHERN (8), with the modification that the DNA was slightly depurinated by exposing the gel to $\mathrm{pH} 2.7$ (5) for 4 hours prior to the denaturing conditions in alkali. This step was introduced to induce hydrolytic cleavage at depurinated sites by the alkali which decreases the molecular weight of large restriction fragments. It resulted in total transfer to the filters, also of the larger restriction fragments, as judged by staining the gels with ethidium bromide after the transfer. The DNA bound to the filters was then hybridized with denatured 32P-labelled pC502 (HIS4) DNA for 48 hours. Autoradiograms of the filters are shown in Figure 1 . When DNA from a HIS4 yeast strain is digested with EcoRI, electrophoresed and probed with $32 \mathrm{P}$ labelled pC502 DNA, 4 bands of 4.1, 3.0, 2.65 and $1.4 \mathrm{~kb}$ are obtained (lane h). his4-260 DNA has an identical pattern (lane i). All 3 deletion strains show an altered hybridization pattern when compared to the wild type (HIS4) or to each other. DNA from his4-29 (lane j) shows only 3 bands. It has retained the upper and lower of the wild type bands $(4.1$ and $1.4 \mathrm{~kb})$ and has a new band at $4.8 \mathrm{~kb}$ instead of the two middle wild type bands. From our physical mapping of the $9.4 \mathrm{~kb}$ PstI fragment (5) we know that the 3.0 and $2.65 \mathrm{~kb}$ fragments are adjacent in the chromosome. The pattern of the his $4-29$ strain therefore shows that the deletion covers the EcoRI site between these two fragments and has

Figure 1. Restriction endonuclease fragments from 4 different his4 mutants.

Samples consisting of about $1 \mu \mathrm{g}$ of DNA digested with the following restriction endonucleases were separated by electrophoresis: BamHI (lanes a-e), EcoRI (lanes f-j), PstI (lanes k-o), HindIII (lanes p-t) and SalI (lanes $\mathrm{u}-\mathrm{y}$ ). Fragments which contain sequences in and around the HIS4 gene were detected by molecular hybridization with $1.5 \cdot 10^{7} \mathrm{cpm}$ of ${ }^{32} \mathrm{P}$. labelled pC502 (5). The DNA was extracted from yeast strains carrying the following his 4 alleles: his $4-$ 29, his4-260, HIS4, his4-15 and his4-24. Lane $\mathrm{z}$ shows EcoRI digested pC501 (5). For better visualization of faint bands after Hindill and Sall digestion a longer exposure is shown to the right. 


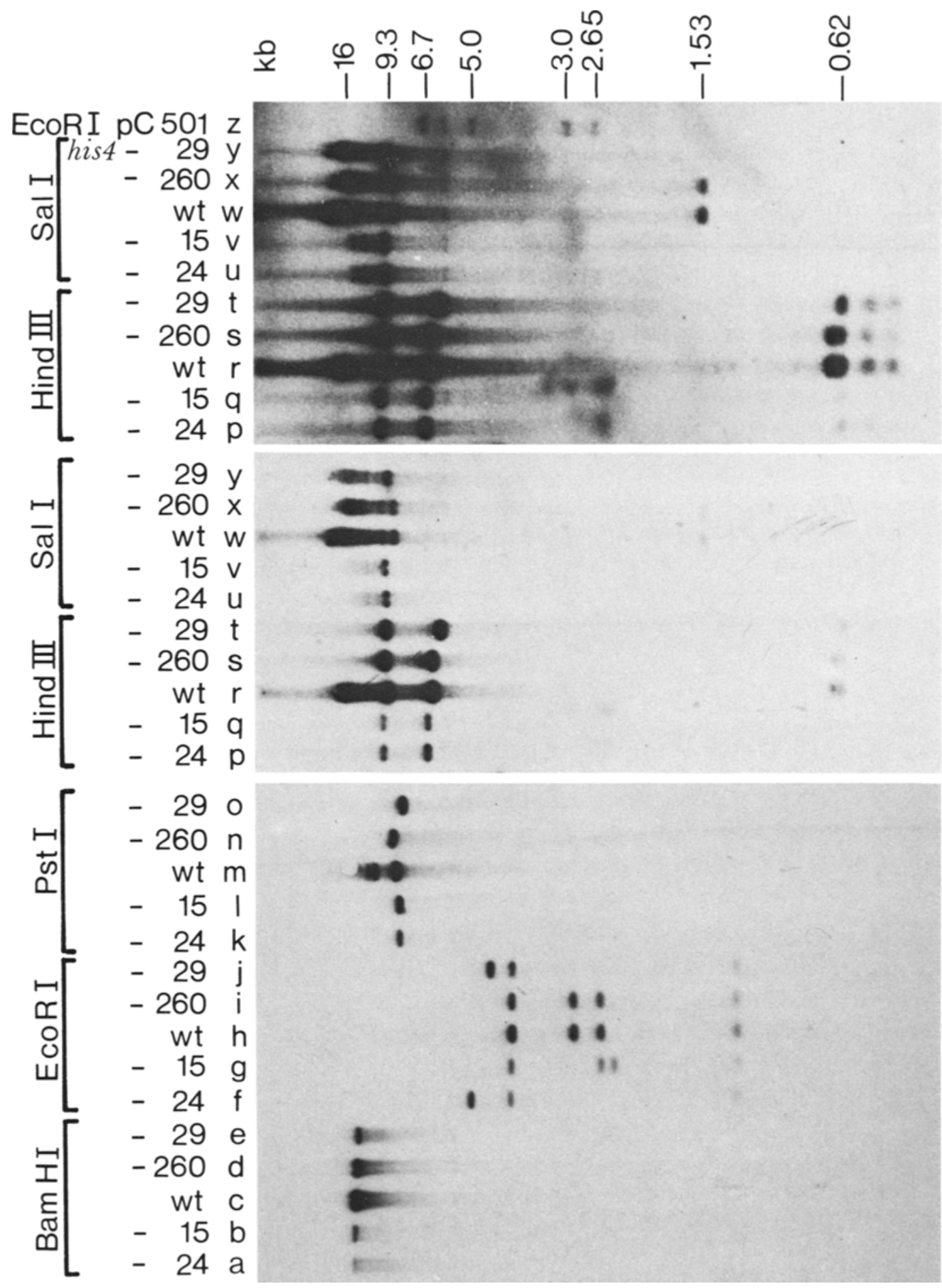


the approximate size of $0.9 \mathrm{~kb}$. The deletion his 4-24 (lane f) shows the same type of change, but here the new band has a mobility corresponding to $5.2 \mathrm{~kb}$ indicating that the his424 deletion covers $0.45 \mathrm{~kb}$. The his $4-15$ deletion shows 4 bands (lane g), 3 of which are identical to wild type bands. The HIS $43.0 \mathrm{~kb}$ fragment is missing and a $2.5 \mathrm{~kb}$ fragment appears, showing that the his4-15 deletion is situated within the $3.0 \mathrm{~kb}$ EcoRI fragment and has a size of $0.5 \mathrm{~kb}$.

The hybridization pattern after cleavage of DNA from the HIS4 strain with HindIII (lane r) reveals 6 fragments of $9.5(\mathrm{H1}), 6.4(\mathrm{H} 2), 0.69$ (H3), $0.62(\mathrm{H} 4), 0.46(\mathrm{H} 5)$ and $0.39 \mathrm{~kb}(\mathrm{H} 6)$. As in the case of the EcoRI digestion, the HindIII pattern of the point mutation (lane s) is identical to that of the wild type (lane r). All 3 deletions show the same type of change when compared to HIS4: The $\mathrm{H} 3$ fragment is missing and the $\mathrm{H} 2$ fragment has changed slightly in size. This shows that $\mathrm{H} 2$ and $\mathrm{H} 3$ are adjacent and that all 3 deletions cover the HindIII site between these two fragments. The deletions his4-15 and his424 are both slightly smaller than the $\mathrm{H} 3$ fragment, since they cause a minor increase in the size of $\mathrm{H} 2$ (lanes $\mathrm{p}$ and $\mathrm{q}$ ). The his $4-29$ deletion must be larger than the $\mathrm{H} 3$ fragment as the $\mathrm{H} 2$ fragment decreases in size (lane $\mathrm{t}$ ).
Although the digestion of the 5 DNA preparations with Sall is incomplete (lanes $u-y$ ), 3 bands in the wild type pattern appear to correspond to total digestion: $S 1$ of about $16 \mathrm{~kb}$, $\mathrm{S} 2$ of $9.3 \mathrm{~kb}$ and $\mathrm{S} 3$ of $1.55 \mathrm{~kb}$. As for the other restriction enzymes the pattern of HIS4 and his4-260 are indistinguishable. The Sall digestion of the DNA from the deletion strains (lanes $u, v$ and $y$ ) shows a pattern analogous to that of the HindIII digestion: The $\mathrm{S} 3$ fragment is absent and the $S 2$ fragment changes in size indicating that all 3 deletions cover the Sall recognition site between these two fragments. In all 3 cases the S2 fragment becomes larger, showing that the deletions are smaller than the $\mathrm{S} 3$ fragment. The S2 fragment is smaller in his4-29 than in the 2 other deletions, again revealing that this deletion is the largest.

Cleavage of the DNA from all 5 strains with either PstI (lanes k-o) or BamHI (lanes a-e) reveals only one band which hybridizes to HIS4 DNA (except for the incompletely digested DNA of lane $\mathrm{m}$ ). The BamHI fragments are bigger than the PstI fragments. This is consistent with the facts that the HIS 4 carrying $9.4 \mathrm{~kb}$ fragment in pC501 (5) originally was isolated after digestion of total yeast DNA with Pstl (6) and that restriction mapping of this PstI fragment

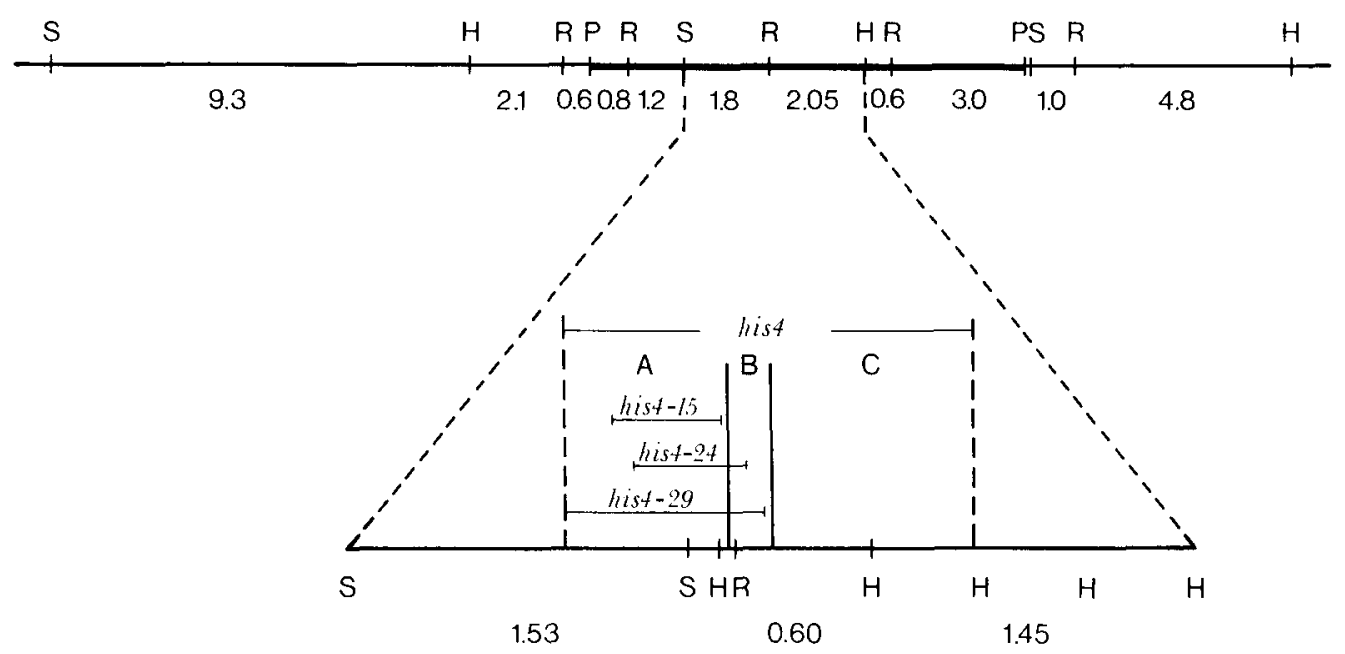

Figure 2. Restriction endonuclease map of the HIS4 region of chromosome III in strain S288C.

$\mathrm{H}, \mathrm{P}, \mathrm{R}$ and $\mathrm{S}$ designate recognition sites for the restriction endonucleases HindIII, Pstl, EcoRI and SalI, respectively. $\mathrm{A}, \mathrm{B}$ and $\mathrm{C}$ designate the his $4 A$, his $4 B$ and his $4 C$ functional segments. The map is complete only between the two PstI sites. 
does not reveal any BamHI recognition sites (5). In this fragment size range the deletions do not cause large and reproducible changes in mobility with the possible exception of his 4-29 (lanes e and o).

Combining the information in Figure 1 with our mapping data (5) we have constructed a restriction endonuclease map of the region on chromosome III containing the HIS4 gene (Figure 2). The EcoRI sites outside the $9.4 \mathrm{~kb}$ Pstl fragment can be positioned as follows: Since the distance from the right end of the cloned DNA to the nearest EcoRI site in this DNA is $3.0 \mathrm{~kb}$, the $1.4 \mathrm{~kb}$ EcoRI fragment observed in chromosomal DNA (Figure 1, lane h) must cover the left end of the cloned DNA. The positions of the 2 Sall sites outside the cloned DNA could be determined, since the deletions extend into the $9.3 \mathrm{~kb}$ Sall fragment. Similarly, the $6.4 \mathrm{~kb}$ wild type HindIIl fragment could be positioned, since it contains part of the deletions. It was not possible to determine the positions of the two BamHI recognition sites. The map is complete for the 5 restriction endonucleases only within the cloned $9.4 \mathrm{~kb}$ region, since the method employed does not allow detection of more than two cleavage sites outside this region for any of the enzymes.

In summary, we have determined the sizes of deletions his4-15 and his 4-24 to be about $0.5 \mathrm{~kb}$ and that of his $4-29$ to be about $0.9 \mathrm{~kb}$. Their approximate positions have been derived from the restriction enzyme cleavage sites which they cover (Figure 2).

\section{DISCUSSION}

The deletions in the his 4 region were isolated and characterized by FinK and STYI.ES (4) by the following two criteria: They did not revert and did not recombine with two or more his4 mutants which recombined with each other. We have shown that three of these mutants are in fact lacking DNA sequences present in the wild type. The genetical positions of the deletions within the his 4 locus (4) allow us to place the his $4 A$, his $4 B$ and his $4 C$ regions on the restriction endonuclease map presented in Figure 2. Deletion his $4-15$ covers the part of his $4 A$ which is proximal to his $4 B$. his $4-24$ covers less of his $4 A$ but extends into his $4 B$. Since the EcoRI site deleted by his4-24 and his4-29 is not deleted by his4-15, this EcoRI site must be at the border between his $4 A$ and his $4 B$ or in the part of his $4 B$ deleted by his $4-24$. This places his $4 B$ to the right of his4-15 and thereby to the right of his $4 A$ on the restriction map in Figure 2. SHAFFER et al. (7) reported that the nonsense mutation his $4-864$ which maps in the very beginning of the $\mathrm{C}$ region instead of the 95,000 molecular weight wild type polypeptide has a polypeptide of approx. 45,000 with $H I S 4 A$ and $H I S 4 B$ activities. Also, the HIS4C activity in his $4-29$ sediments more slowly in a sucrose gradient than the normal complex (4). Assuming that the his 4-29 deletion is extending to or beyond the beginning of the his $4 A$ coding region, we can therefore conclude that the region covered by the deletion codes for a little less than 45,000 of molecular weight of the wild type his 4 protein. With an average molecular weight of an amino acid residue of 110 this corresponds to 400 amino acids of $1.2 \mathrm{~kb}$ of coding region. Since his $4-29$ has been found to be of about the same size $(0.9 \mathrm{~kb})$ we suggest that there are no large intervening sequences in the his $4 A$ or his $4 B$ regions.

\section{ACKNOWLEDGEMENTS}

The gift of E. coli DNA polymerase I from $\mathrm{H}$. KLENow is gratefully acknowledged. We wish to thank D. vON WETTSTEIN for support and critical reading of the manuscript, $B$. WILKEN and J. V. HANSEN for technical assistance and B. E. Christensen and C. Guermansen for interest and stimulating discussions. This work was supported by grant $511-15547,512-15640$ and 516-15099 from the Danish National Research Councils to D. von WeTtSTEIN.

\section{REFERENCES}

1. Bigeu.is, R., J. Kefsey \& G. R. Fink: The HIS4 fungal gene cluster is not polycistronic. In: Molecular Approaches to Eucaryotic Genetic Systems, G. Wilcox, J. Abelson and C. F. Fox eds.. Academic Press, New York - San Francisco - London, pp. 179-187 (1977)

2. Fink, G. R.: Gene-enzyme relations in histidine biosynthesis in yeast. Science 146, 525-527 (1964) 
3. FINK, G. R.: A cluster of genes controlling three enzymes in histidine biosynthesis in Saccharomyces cerevisiae. Genetics 53, 445-459 (1966)

4. Fink, G. R. \& C. A. Styles: Gene conversion of deletions in the HIS4 region of yeast. Genetics 77, 231-244 (1974)

5. Holmberg, S., J. G. L. Petersen, T. NilssonTillgren \& M. C. Kielland-Brandt: Molecular characterization of a Saccharomyces plasmid containing the HIS4 gene. Carlsberg Res. Commun. 44, 269-282 (1979)
6. Kielland-Brandt, M. C., T. Nilsson-Tillgren, S. Holmberg, J. G. L. Petersen \& B. A. SVENNINGSEN: Transformation of yeast without the use of foreign DNA. Carlsberg Res. Commun. 44, 77-87 (1979)

7. Shaffer, B., J. Rytka \& G. R. Fink: Nonsense mutations affecting the HIS4 enzyme complex of yeast. Proc. Nat. Acad. Sci. USA 63, 1198-1205 (1969)

8. Southern, E. M.: Detection of specific sequences among DNA fragments separated by gel electrophoresis. J. Mol. Biol. 98, 503-517 (1975) 